Original Article

\title{
UV-SPECTROPHOTOMETRIC METHOD DEVELOPMENT AND VALIDATION FOR ESTIMATION OF IPRATROPIUM BROMIDE IN API AND PHARMACEUTICAL DOSAGE FORM
}

\author{
ANJALI P. KOKANE*, VARSHA S. TEGELI, BHAGYASHRI S. SHINDE \\ Department of Quality Assurance D. S. T. S. Mandal's College of Pharmacy, Solapur, Maharashtra, India \\ Email: anjalikokane333@gmail.com
}

Received: 26 Jan 2020, Revised and Accepted: 24 Mar 2020

\section{ABSTRACT}

Objective: The current work intended towards the developed and validated by using Simple, rapid, sensitive, precise and specific method UV Spectrophotometric method for the estimation of Ipratropium bromide in API and pharmaceutical formulation.

Methods: Water used as a solvent and the absorbance of the drug was measured at the absorbance's maxima of Ipratropium bromide $\lambda$ max is 214 nm.

Result: Calibration curve plotted in concentration range $20-120 \mu \mathrm{g} / \mathrm{ml}$ exhibit the linearity relationship with line equation $\mathrm{y}=0.0062 \mathrm{x}+0.3161$ and $\mathrm{r}^{2}=0.995$. The Accuracy was found to be $99.5-100.1 \%$, the precision \% RSD $=0.12888-0.30533$, and the LOD and LOQ is $8.78266-28.5881$. The method was found to comply with all the validation parameters as per ICH guidelines indicating the sensitivity of the method towards analyte.

Conclusion: The method can be used satisfactory for the routine analysis of Ipratropium Bromide present in API and Pharmaceutical dosage form.

Keywords: Ipratropium bromide, UV spectrophotometer, Method validation

(C) 2020 The Authors. Published by Innovare Academic Sciences Pvt Ltd. This is an open access article under the CC BY license (http://creativecommons.org/licenses/by/4.0/) DOI: http://dx.doi.org/10.22159/ijcpr.2020v12i3. 38309. Journal homepage: https://innovareacademics.in/journals/index.php/ijcpr

\section{INTRODUCTION}

Ipratropium bromide is a muscarinic cholinergic antagonist and is used in asthma. Ipratropium bromide has bronchial smooth muscle relaxant properties due to its action on muscarinic receptor. Ipratropium bromide is a bromide salt form of Ipratropium, synthetic derivative of alkaloid atropine with anticholinergic properties. It is used in treating symptoms of asthma, cold, chronic obstructive pulmonary disease due to chronic bronchitis. Ipratropium bromide is short-acting anticholinergic drug in asthma.

Chemical name is (1R,3R,5S,8R)-3-[(3-hydroxy-2-phenyl propanoyl) oxy]-8-methyl-8 (propan-2-yl) 8-azabicyclo [3.2.1] octan-8-iumbromide.

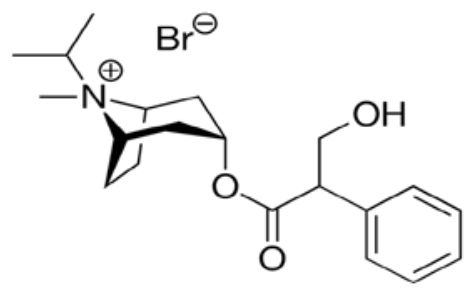

Fig. 1: Chemical structure of Ipratropium bromide

Literature survey reveals that the Ipratropium bromide has been estimated by RP-HPLC ${ }^{1}$, LC/MS, HPTLC with fluorescence detection.

The aim of work is to develop UV spectrophotometry and RP-HPLC [2-6] method for the estimation of Ipratropium bromide in pharmaceutical formulation.

\section{MATERIALS AND METHODS}

Instrument

For weighing a calibrated weighing balance (Shimadzu AY220) of 1 $\mathrm{mg}$, sensitivity was used. A systronics UV visible double beam spectrophotometer 2201 was used with $1 \mathrm{~cm}$ matched quartz cell. All the glassware were made of borosilicate and were calibrated.

Chemicals

API-Ipratropium bromide pure API was gifted by Vamsi Pharmaceutical Ltd. Solapur, Maharashtra.

UV spectroscopic method

Solvent selection

Ipratropium bromide is soluble in water so the water was used as the solvent.

\section{Preparation of standard stock solution}

The standard stock solution of Ipratropium bromide was prepared by transferring accurately weighed $10 \mathrm{mg}$ of Ipratropium bromide into $10 \mathrm{ml}$ volumetric flask containing $5 \mathrm{ml}$ of water, dissolve properly. The volume was made up to the mark by using water to give a concentration of $1000 \mu \mathrm{g} / \mathrm{ml}$, from this $4 \mathrm{ml}$ of the solution was transferred to $20 \mathrm{ml}$ of volumetric flask and made up the volume with water to give a concentration of $200 \mu \mathrm{g} / \mathrm{ml}$ which is a standard solution and it is further diluted with water to get concentration range $20-120 \mu \mathrm{g} / \mathrm{ml}$.

\section{Determination of absorption maxima}

The standard stock solution of $200 \mu \mathrm{g} / \mathrm{ml}$ was scanned in the range of 200-400 nm to determine the wavelength of maximum absorption. The drug showed maximum absorption at $214 \mathrm{~nm}$.

\section{Preparation of calibration curve}

For the preparation of calibration curve solutions of concentration $20-120 \mu \mathrm{g} / \mathrm{ml}$ were prepared by pipetting out $1,2,3,4,5,6, \mathrm{ml}$ of $200 \mu \mathrm{g} / \mathrm{ml}$ solution into $10 \mathrm{ml}$ volumetric flask and made up the volume up to the mark with water. The absorption of each solution was measured at $214 \mathrm{~nm}$ against water as blank. Calibration curve of the Ipratropium bromide was plotted by taking the absorption obtained on the Y-axis and concentration of the solution on the Xaxis. The curve showed linearity in the range of $20-120 \mu \mathrm{g} / \mathrm{ml}$ with a correlation coefficient of 0.9954 . 


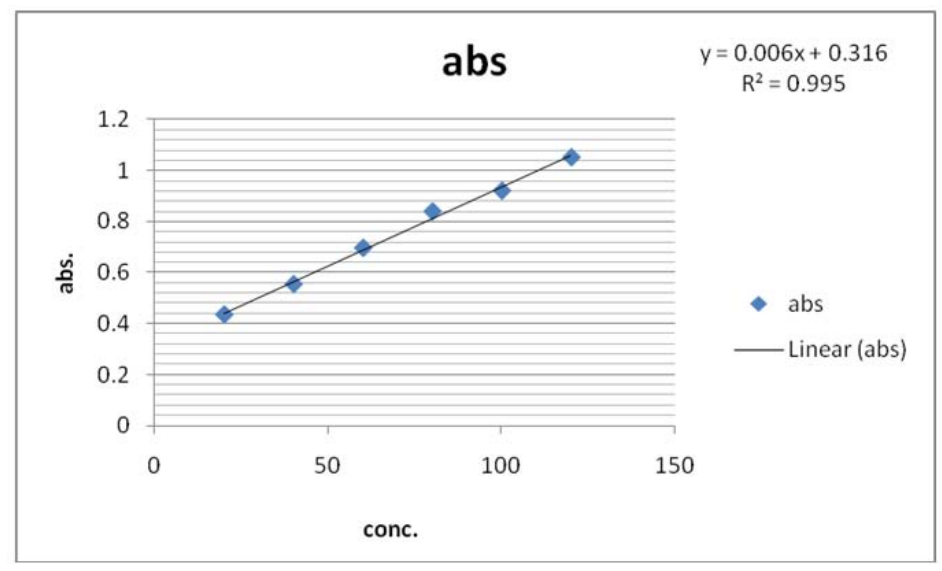

Fig. 2: Calibration curve of ipratropium bromide (IPRA)

\section{Method validation}

The developed method was validated as per ICH guidelines for the following parameters.

\section{Linearity}

$1,2,3,4,5,6 \mathrm{ml}$ of standard Ipratropium bromide solution was transferred into a series of $10 \mathrm{ml}$ volumetric flask. The volume was made up to the mark with water to obtain the concentration of 20 , $40,60,80,100,120 \mu \mathrm{g} / \mathrm{ml}$. The absorption of these solutions was recorded and the graph of absorption against concentration was plotted. The correlation coefficient $\left(\mathrm{r}^{2}\right)$ of the least squares linear regression of Ipratropium bromide was calculated.

\section{Range}

The range of the analytical method was decided from the interval between the upper and lower level of the calibration curve by plotting the curve.

\section{Accuracy}

The recovery study was carried out by the standard addition method by adding the known amount of Ipratropium bromide to the pre-analyzed sample at three different concentration levels that are $80 \%, 100 \%$, $120 \%$ of assay concentration and percent recovery were calculated.

$$
\% \text { Recovery }=\text { observed value/true value } * 100
$$

\section{Precision}

The precision of an analytical procedure expresses the closeness of agreement (degree of scatter) between a series of measurements obtained from multiple sampling of the same sample under the prescribed condition. The precision of the method was determined in term of repeatability, intra-day precision and inter-day precision (Intermediate precision). Intra-day precision was determined by analyzing the drug at the concentration $(60 \mu \mathrm{g} / \mathrm{ml})$ and each concentration for these two times on the same day. Inter-day precision was determined similarly, but the analysis is carried out daily for the two consecutive days.

Repeatability: Repeatability of the method was determined by analyzing six samples of the same concentration of the drug $60 \mu \mathrm{g} / \mathrm{ml}$. The absorbance of each was measured.

\section{Robustness}

The robustness of the developed method is its capacity to remain unaffected by small changes in altered concentration. To determine the robustness of the method, the wavelength was studied at $\pm 5 \mathrm{~nm}$.

\section{Ruggedness}

Ruggedness was determined by carrying out the analysis by two different analysts and the respective absorbance was noted and the results were indicated as \% RSD.

\section{Limit of detection}

Detection limit was determined based on the standard deviation of absorbance of same concentration that is a standard stock solution of Ipratropium bromide $(60 \mu \mathrm{g} / \mathrm{ml})$ and LOD was calculated by $\mathrm{LOD}=3.3(\mathrm{SD} / \mathrm{S})$.

Where, SD-standard deviation; S-slope of the curve

\section{Limit of quantification}

Quantification limit was determined based on the standard deviation of the peak area of same concentration that is a standard solution of Ipratropium bromide $(60 \mu \mathrm{g} / \mathrm{ml})$ was prepared six times and $\mathrm{LOQ}=10(\mathrm{SD} / \mathrm{S})$.

Where, SD-standard deviation; S-slope of the deviation.

\section{RESULTS}

\section{Preliminary analysis of drug}

Observation and Results of Preliminary Analysis of Ipratropium bromide.

\section{Linearity}

The linearity of this method was determined at range from 20-120 $\mu \mathrm{g} / \mathrm{ml}$ for the Ipratropium Bromide the regression equation was found to be $0.0062 x+0.3161, R^{2}=0.995$

\section{Accuracy}

The accuracy of the analytical method for Ipratropium Bromide was determined at $80,100,120 \%$ level of the standard solution. Absorbance was measured at $214 \mathrm{~nm}$ and the results were expressed in the term of \% recovery.

\section{Precision}

The precision (measurement of intra-day, inter-day and repeatability) result showed good reproducibility with the relative standard deviation (\%RSD) below 0.12888-0.30533 and this indicates that the method was highly precise.

Table 1: Preliminary analysis of drug

\begin{tabular}{lll}
\hline Test & Observation & Result \\
\hline Description & White powder & Complied \\
Solubility & Soluble in water, methanol & Complied \\
\hline
\end{tabular}




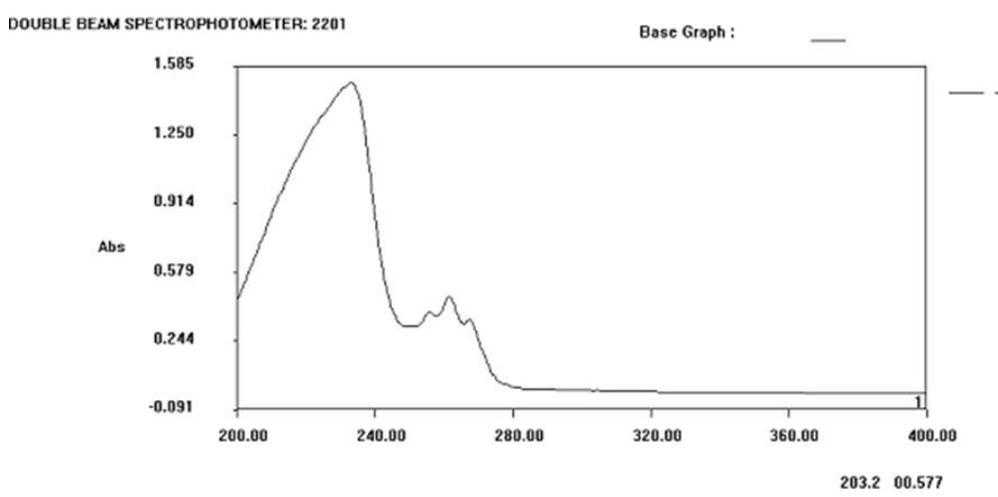

Fig. 3: Determination of wavelength of maximum absorption was found to be $214 \mathrm{~nm}$

Table 2: Linearity

\begin{tabular}{lll}
\hline S. No. & Conc. $(\mu \mathrm{g} / \mathbf{m l})$ & Absorbance \\
\hline 1 & 20 & 0.434 \\
2 & 40 & 0.553 \\
3 & 60 & 0.695 \\
4 & 80 & 0.838 \\
5 & 100 & 0.919 \\
6 & 120 & 1.105 \\
\hline
\end{tabular}

The linearity for Ipratropium bromide was found to be linear in the range of $20-120 \mu \mathrm{g} / \mathrm{ml}$ with $\mathrm{R}^{2}=0.995$ and the strainght line equation as $\mathrm{y}=0.0062 \mathrm{x}+0.3161$

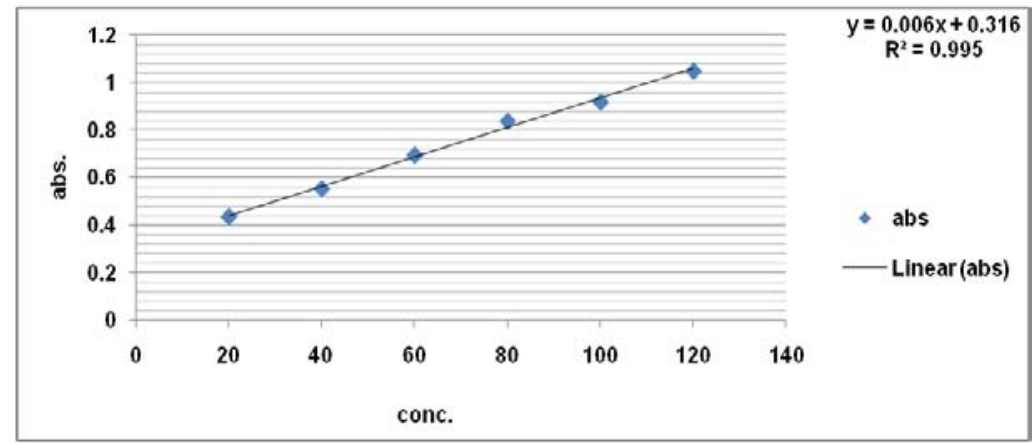

Fig. 4: The accuracy of the analytical method for Ipratropium Bromide was determined at 80, 100, 120\% level of the standard solution. Absorbance was measured at $214 \mathrm{~nm}$ and the results were expressed in the term of \% recovery

Table 3: Accuracy

\begin{tabular}{lllllll}
\hline S. No. & \% level & Spike amount $(\boldsymbol{\mu g} / \mathbf{m l})$ & Spiked amount (wrt. sample) & Abs. & Amount recovered & \% RSD of $\%$ recovery \\
\hline 1 & 80 & 79.840 & 79.8 & 0.735 & 99.5 \\
2 & 100 & 99.800 & 99.8 & 0.919 & 99.5 \\
3 & 120 & 119.760 & 119.8 & 1.105 & 100.1 & 0.3 \\
\hline
\end{tabular}

Table 4: Intra-day morning precision

\begin{tabular}{|c|c|c|c|c|}
\hline S. No. & Concentration $(\mu \mathrm{g} / \mathrm{ml})$ & Absorbance & SD & \% RSD \\
\hline 1. & 60 & 0.694 & & \\
\hline 2. & 60 & 0.695 & 0.00089443 & 0.12888 \\
\hline 3. & 60 & 0.694 & & \\
\hline 4. & 60 & 0.693 & & \\
\hline 5. & 60 & 0.693 & & \\
\hline 6. & 60 & 0.695 & & \\
\hline
\end{tabular}

Table 5: Inter-day precision

\begin{tabular}{llll}
\hline S. No. & Concentration & Absorbance & \%SD \\
\hline 1. & 60 & 0.683 & 0.00209762 \\
2. & 60 & 0.689 & 0.30533009 \\
3. & 60 & 0.688 & \\
4. & 60 & 0.687 & \\
5. & 60 & 0.687 & \\
6. & 60 & 0.688 & \\
\hline
\end{tabular}




\section{Limit of detection}

For the limit of detection

\section{Limit of quantification}

For Limit of Quantification

\section{Robustness}

For Robustness

\section{Ruggedness}

Ruggedness was determined by carrying out the analysis by two different analyst and the respective absorbance was noted and the results were indicated as $\% \mathrm{RSD}$.

\section{DISCUSSION}

Preliminary analysis of Ipratropium bromide such as description, solubility was performed.

\section{UV spectrophotometry for Ipratropium bromide}

\section{Selection of wavelength}

Ipratropium bromide showed the maximum absorbance at $214 \mathrm{~nm}$ Hence, analysis is carried out at $214 \mathrm{~nm}$. Ipratropium bromide showed absorption maxima at $214 \mathrm{~nm}$ and obeyed Beer's law in the concentration range of $20-120 \mu \mathrm{g} / \mathrm{ml}$ with the correlation coefficient 0.995 which is within acceptance criteria. The accuracy was from 99.5 and $100.1 \%$ at $214 \max 200-400 \mathrm{~nm}$, respectively. The \%RSD less than showed the method is precise. The limit of detection (LOD) was found to be 8.78266 and the limit of qualification (LOQ) to be 28.5881 , respectively.

\section{Summary and conclusion}

A simple, precise, rapid and accurate UV method for determination of Ipratropium bromide from pure and its tablet formulation has been developed and validated. The proposed method can be used for the routine determination of Ipratropium bromide in bulk and pharmaceutical dosage formulation.

Table 6: Limit of detection

$\begin{array}{ll}\mathrm{LOD}(\mu \mathrm{g} / \mathrm{ml}) & 8.78266\end{array}$

Table: 7 Limit of quantification

\begin{tabular}{ll}
\hline $\mathrm{LOQ}(\mu \mathrm{g} / \mathrm{ml})$ & 28.5881
\end{tabular}

Table 8: For robustness

\begin{tabular}{|c|c|c|c|c|}
\hline S. No. & Wavelength & Absorbance & SD & \%RSD \\
\hline \multirow[t]{4}{*}{1.} & 214 & 0.434 & & \\
\hline & & 0.436 & 0.002 & 0.4587 \\
\hline & & 0.438 & & \\
\hline & & Avg. $=0.436$ & & \\
\hline \multirow[t]{4}{*}{2.} & 216 & 0.432 & & \\
\hline & & 0.437 & 0.004 & 0.9262 \\
\hline & & 0.440 & & \\
\hline & & Avg. $=0.436$ & & \\
\hline
\end{tabular}

Table 9: Ruggedness

Analyst 1

\begin{tabular}{lll}
\hline Concentration & Absorbance & Statistical analysis \\
\hline 60 & 0.683 & Avg. $=0.684$ \\
60 & 0.684 & SD $=0.001$ \\
60 & 0.685 & $\%$ RSD $=0.1461$ \\
\hline & & Analyst 2 \\
& \\
\hline Concentration & & Statistical analysis \\
\hline 60 & Absorbance & Avg. $=0.685$ \\
60 & 0.684 & SD $=0.001$ \\
60 & 0.685 & $\%$ RSD $=0.1459$ \\
\hline
\end{tabular}

Table 10: Summary of UV spectrophotometry method of Ipratropium bromide

\begin{tabular}{lll}
\hline S. No. & Parameter & Values(214 nm) \\
\hline 1. & Beers law limit $(\mu \mathrm{g} / \mathrm{ml})$ & $20-120$ \\
2. & Absorption maxima $(\mathrm{nm})$ & $214 \mathrm{~nm}$ \\
3. & Correlation coefficient $\left(\mathrm{r}^{2}\right)$ & 0.995 \\
4. & Standard regression equation & $0.0062 \mathrm{x}+0.3161$ \\
5. & Accuracy (\%recovery) & $99.5-100.1 \%$ \\
6. & Precision (\%RSD) & $0.12888-0.30533$ \\
& Inter-day & 0.12888 \\
7. & Intra-day & 0.30533 \\
8. & LOD & 8.78266 \\
9. & LOQ & 28.5881 \\
10 & Robustness (\%RSD) & 0.4587 and 0.9262 \\
\end{tabular}

The development of a validated method for the determination of Ipratropium bromide at $\lambda$ max has shown a similar result; therefore, analysis can be done either at $214 \mathrm{~nm}$ with the same accuracy and precision. 


\section{FUNDING}

Nil

\section{AUTHORS CONTRIBUTIONS}

All the authors have contributed equally.

\section{CONFLICT OF INTERESTS}

Declare none

\section{REFERENCES}

1. R Vankudoth, RP Pulla, B Umasankar, G Saisneha, S Chawan, A Aparna. RP-HPLC method for simultaneous estimation of Ipratropium bromide and levolbutamol in pharmaceutical metered-dose inhalers. Int J Res Pharm Chem 2013;3:2231781.

2. GB Kasawar, M Faooqui. Development and validation of stability indicating RP-HPLC for the simultaneous determination of the related substance of albuterol sulphate and ipratropium bromide in nasal solution. J Pharm Biomed Anal 2010;52:19-20.

3. A Rasheed, 0 Ahmed. Analytical separation and characterization of degradation product and the development and validation of stability indicating method for the estimation of impurities in Ipratropium bromide respules formulation. Int J Appl Pharm Sci Res 2017;2:55-63.

4. P Nagarju, SCHVSS Appaji. Development and validation of novel RP-HPLC method for simultaneous estimation of levosalbutamol and Ipratropium bromide in pharmaceutical dosage form. Int J Res Pharm Chem 2014;4:635.

5. Gummadi Sowjanya D, Gowri Sankar JVLN, Seshagiri Rao. Development and validation of a new RP-HPLC method for the simultaneous determination of albuterol sulphate and ipratropium bromide in nasal inhalation. Int Res J Pharm 2018;9:63-70.

6. K Kranthi Kiran. A new analytical method development and validation for the simultaneous estimation of albuterol and Ipratropium bromide using RP-HPLC. Int J Pharm Investigation Res 2017;4:63-70. 